Sabine K. Klaus

\title{
Wieprecht versus Sax. The German Roots of Adolphe Sax's Brasswind Designs
}

Antoine-Joseph Sax(I8I4-I894), known always as Adolphe, was an ingenious but troubled man. The legal battles that took place between him and his Parisian rivals are well documented, but these were not the only attacks that he endured in his lifetime. In this article I shall focus on accusations brought against Sax by the Prussian music director Wilhelm Wieprecht (I802-I872) in Berlin, and investigate whether or not they were justified.

Wieprecht had moved from Leipzig to Berlin in I824, subsequently becoming the director of all Prussian military bands. ${ }^{\mathrm{I}}$ He reorganised Prussian military music as a whole, invented the Berlin valve, and together with the instrument maker Johann Gottfried Moritz (I777-I840) patented the bass tuba. Twelve years older than Sax, Wieprecht was well established by the time Sax moved from Brussels to Paris in late I842. Sax was no doubt thoroughly acquainted with Wieprecht's and Moritz's instrument designs, and reportedly had travelled to Berlin to study them before settling in Paris. ${ }^{2}$ According to Wieprecht, either Sax or his son had bought a bass tuba and several cornets from the instrument maker Moritz in Berlin. ${ }^{3}$ This statement cannot be entirely correct, however, because Adolphe Sax's son Adolphe-Édouard was only born in 1859. ${ }^{4}$ However, it is possible that Wieprecht was erroneously referring to Adolphe Sax's younger brother Antoine-Alphonse (I822-I874) as his "son". Antoine-Alphonse Sax worked for his older brother in Paris between I843 and I845 before establishing his own workshop in Brussels in 1845 . Be it as it may, a bass tuba by Carl Wilhelm Moritz and Wieprecht, made in Berlin in circa I840, was indeed part of Sax's private musical instrument collection. ${ }^{5}$

Wieprecht and Sax meet in Koblenz in the summer of $\mathbf{1 8 4 5}$ The main documentary source for Wieprecht's attack on Sax is a pamphlet with the title "Der Instrumentenmacher Sax in Paris als Erfinder" (The Instrument Maker Sax in Paris as Inventor), written in I845

For details on Wieprecht's life see August Kalkbrenner: Wilhelm Wieprecht, Director der sämmtlichen Musikchöre des Garde-Corps. Sein Leben und Wirken nebst einem Auszug seiner Schriften, Berlin I882, reprint ed. by Verena Paul, Vienna 20I5 (IGEB Reprints, Vol. 7). Adolphe le Doulcet, comte de Pontécoulant: Organographie. Essai sur la facture instrumentale, art, industrie, et commerce, Paris I86I, reprint Amsterdam I972, Vol. 2, p. 225. Kalkbrenner: Wilhelm Wieprecht, p. 93.

William Waterhouse: The New Langwill Index, London I993, p.348.

Géry Dumoulin: Catalogue Sax200, Liège 20I4, p.80. 
and published posthumously in August Kalkbrenner's biography of Wieprecht. ${ }^{6}$ In this pamphlet, Wieprecht describes his meeting with Sax in Franz Liszt's apartment in Koblenz during the summer of $\mathrm{I} 845$. Wieprecht spent that summer in Koblenz in order to direct performances in honour of Queen Victoria and Prince Albert on their visit to Germany. When they met, Wieprecht and Sax took the opportunity to compare their instruments. Sax was accompanied by the 20-year-old cornetist Jean-Baptiste Arban (I825-I889), who was still a student at the Paris Conservatoire at the time. Arban played both Sax's instruments and Wieprecht's with equal virtuosity. After the meeting at Liszt's, Wieprecht went to Sax's hotel room to see more of his instruments. Based on this inspection, Wieprecht concluded that all of Sax's models were German inventions:

"Our Cornettino in $\mathrm{E} b$ he calls Saxhorn en mi-b[émol] (soprano).

Our Cornetto in Bb he calls Saxhorn en si-b[émol].

Our Cornetto Alto in $\mathrm{E} b$ he calls Saxhorn en mi-b[émol].

Our tenor horn in $\mathrm{B} b$ he calls Saxhorn en si-b[émol] (Bariton en basse).

Our basstromba in Eb he calls Saxhorn en mi-b[émol] (Basse).

Our bass tuba he calls Saxhorn en mi-b[émol] (Contrebasse)."7

In Wieprecht's opinion it was therefore unjustified to affix the name "Sax" to all these models. Wieprecht's use of the terms cornettino and cornetto may well have been inspired by the soft timbre of the real cornetto (the wooden, leather-covered, lip-reed instrument with fingerholes) that was still played from some church towers in Germany at that time, for example in Stuttgart, where Jean-Georges Kastner heard it in the early I840s. ${ }^{8}$ The term cornetto, abbreviated to cornet, was generally used for the higher sizes of Wieprecht's wide-bore brasswind family with a barely flaring, almost conical bell. Now they are known as Prussian cornets (named after their region of origin, Prussia) to distinguish them from the French cornet à pistons with narrower bore and wide flaring bell.

Wieprecht's Berlin valve and bass tuba After applying unsuccessfully for a patent for valve improvements in I833, 9 Wieprecht and the Berlin musical instrument maker Johann Gottfried Moritz received a patent for a bass tuba in I835 (Figure I). This patent only

6 Wilhelm Wieprecht: Der Instrumentenmacher Sax in Paris als Erfinder, in: Kalkbrenner: Wilhelm Wieprecht, pp. 88-97.

7 "Unser Cornettino in Es nennt er Saxhorn en mi-b (soprano). Unser Cornetto in B nennt er Saxhorn en si-b. Unser Cornetto Alto in Es nennt er Saxhorn en mi-b. Unser Tenorhorn in B nennt er Saxhorn en si-b (Bariton en basse). Unsere Baßtromba in Es nennt er Saxhorn en mi-b (Basse). Unsere Baß= Tuba nennt er Saxhorn en mi-b (Contrebasse)." Ibid., p. 93.

8 Jean-Georges Kastner: Supplément au Traité général d'instrumentation, Paris: Prilipp [I844], p. 42.

9 Geheimes Staatsarchiv Preußischer Kulturbesitz, Berlin, Rep. I20, Ministerium für Handel und Gewerbe, D XIV 2, No.33, Vol. I, pp. 85-9I. 
protected the specific arrangement of additional tubing and the bell design, because these two elements were judged to be new inventions. ${ }^{\text {IO }}$ The Prussian patent law, introduced on I4 October I8I5, strictly distinguished between new inventions and improvements; only new inventions could be protected by patents. ${ }^{\text {II }}$ This meant that only the exact design of the bass tuba was covered by the patent, not Wieprecht's valve improvements, the so-called Berlin valve, because the idea of applying valves to brass instruments was not new. According to his own account, in developing the Berlin valve Wieprecht had been inspired by Heinrich Stölzel's Röhrenschiebeventil and Friedrich Blühmel's rotary valve. By combining the advantages of these two valve systems, Wieprecht preserved the ease of operation and maintenance of the Stölzel valve, while at the same time gaining a more beautiful tone as a result of the smoother windway of the rotary valve. ${ }^{\mathrm{I2}}$

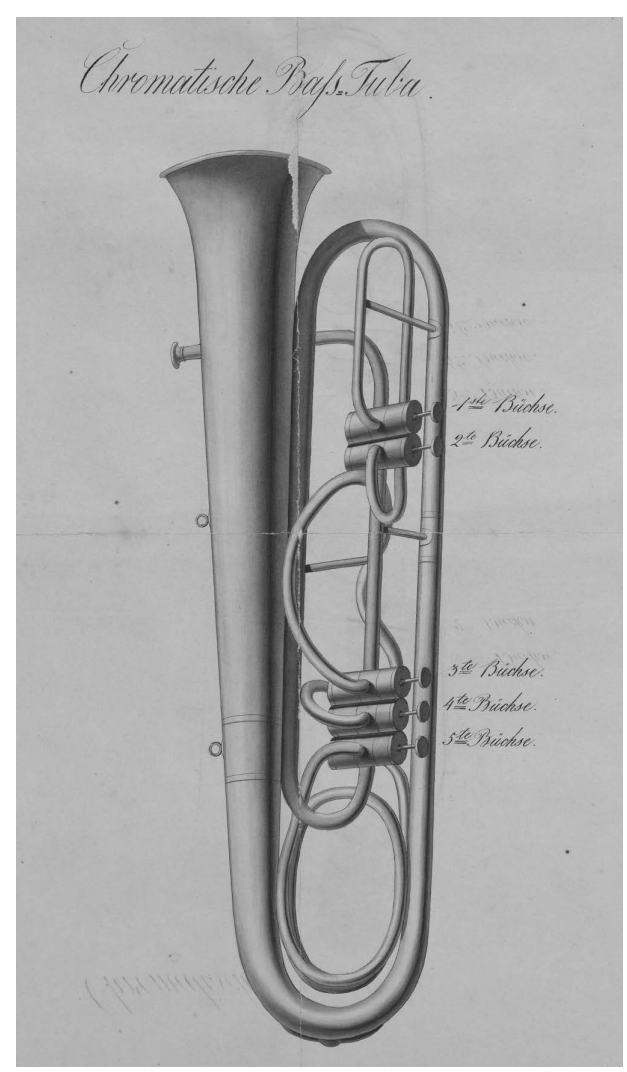

FIGURE 1 Drawing of the bass tuba by Wilhelm Wieprecht and J. G. Moritz from the patent application of 18 July 1835 (Geheimes Staatsarchiv, Preußischer Kulturbesitz, Rep.120, Ministerium für Handel und Gewerbe, D XIV 2, No. 33, Vol. 1)

"[...] bei dem von Ihnen angegebenen Blase-Instrumente - Bass-Tuba - nur die Gestaltung und Anordnung der Einsatzröhren und des Schallstück-Systems für eigenthümlich befunden worden ist." Ibid., p. 99.

11 Christiane Brandt-Salloum: “... eine Ausnahme von der allgemeinen Regel der Gewerbefreiheit?” Patente zwischen praktischer Gewerbeförderung und wirtschaftsliberalem Dogma, in: Klosterstrasse 36. Sammeln, Ausstellen, Patentieren. Zu den Anfängen Preußens als Industriestaat, Berlin 20I4, PP. 2I-4I, especially p. 26.

12 Wieprecht: Der Instrumentenmacher Sax, p. 90. 
Sax's adaptation of the Berlin valve Sax discussed various German valve types retrospectively in his patent of $\mathrm{r} 862 .{ }^{\mathrm{I} 3}$ In Figure I of his patent application he illustrated the Stölzel valve and criticised it for its sharp angles in the windway, indicating them by red lines (see Figure 2). However, in the same patent Sax also mentioned that piston-operated valves had the advantage of an easy and reliable operating mechanism. Rotary valves (Figure v in the patent, here Figure 3) were in Sax's opinion superior to the Stölzel valve on account of their smooth windway, but suffered from a complicated operating mechanism. In the Berlin valve (Figure vi in the patent, here Figure 4), Sax saw the two advantages combined: an easy operating mechanism (Stölzel valve) and a smooth windway (rotary valve). By presenting this argument, Sax revealed the reasons for his preference for the Berlin valve for so much of his output: he valued it for exactly the same reasons for which Wieprecht had developed it. In Sax's patents, catalogues and handbills, the Berlin valve is referred to as cplindres and used for whole families as well as individual instrument types. In his patent of 1843 , in which he used a modification of the Berlin valve for the first time, Sax introduced completely circular valve loops "to suppress the angles in the added tubing of the cylinders or pistons, so as to conserve in wind instruments their original sonority." "I4 Sax's idea was basically to create valve loops like crooks in a continuous circle (Figure 5). A contralto saxhorn and a valve trombone by Sax with circular valve loops, dating from I846 and I847 respectively, survive at the Musée de la musique in Paris (E.740 and E.729).

Wieprecht and Moritz, too, used circular valve loops at first, but like Sax gave up this idea in favour of valve slides. However, Sax's designs continued to differ from Wieprecht's and Moritz's Prussian models. While the Prussian instruments had valve loops exit and re-enter at a $90^{\circ}$ angle to the main windway (Figure 6), Sax placed the exit and re-entry of the tubing at various different inclinations to make the windway smoother (Figure 7).

Wieprecht's instrument models compared with Sax's saxhorns and saxotrombas According to Hector Berlioz, Sax made copies of Wieprecht's bass tuba in Paris before $1844 .{ }^{\text {I5 }}$ Among the instruments illustrated in Sax's I843 patent is a Contrebasse d'harmonie (Figure 8), which is indeed a modification of Wieprecht's bass tuba. It has six Berlin valves

French Patent No.54212, granted I9 May 1862. My thanks to Steeve Gallizia (Fond d'archives de l'Institut national de la proprieté industrielle, Paris) for providing reproductions of the French patents reproduced here.

"Il supprime aussi les angles dans les tons ajoutés aux cylindres ou pistons, de manière à conserver aux instruments à vents leur sonorité première." French Patent No. I5364, granted I7 August 1843. 


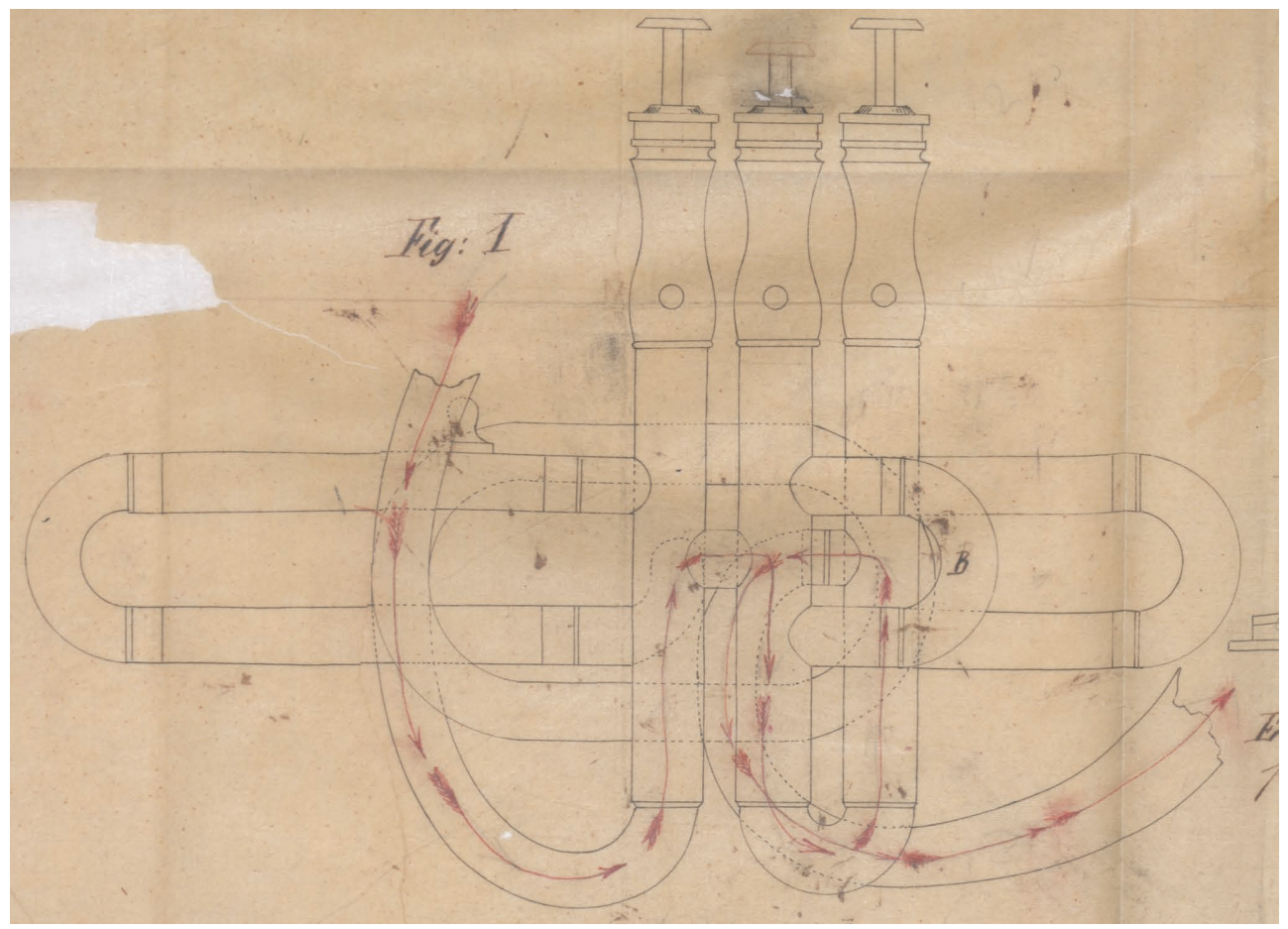

Figure 2 The Stölzel valve with its angles in the windway as illustrated in Sax's French patent No. 54212 of 1862. (c) Fond d'archives de l'Institut national de la proprieté industrielle, Paris (IN PI)

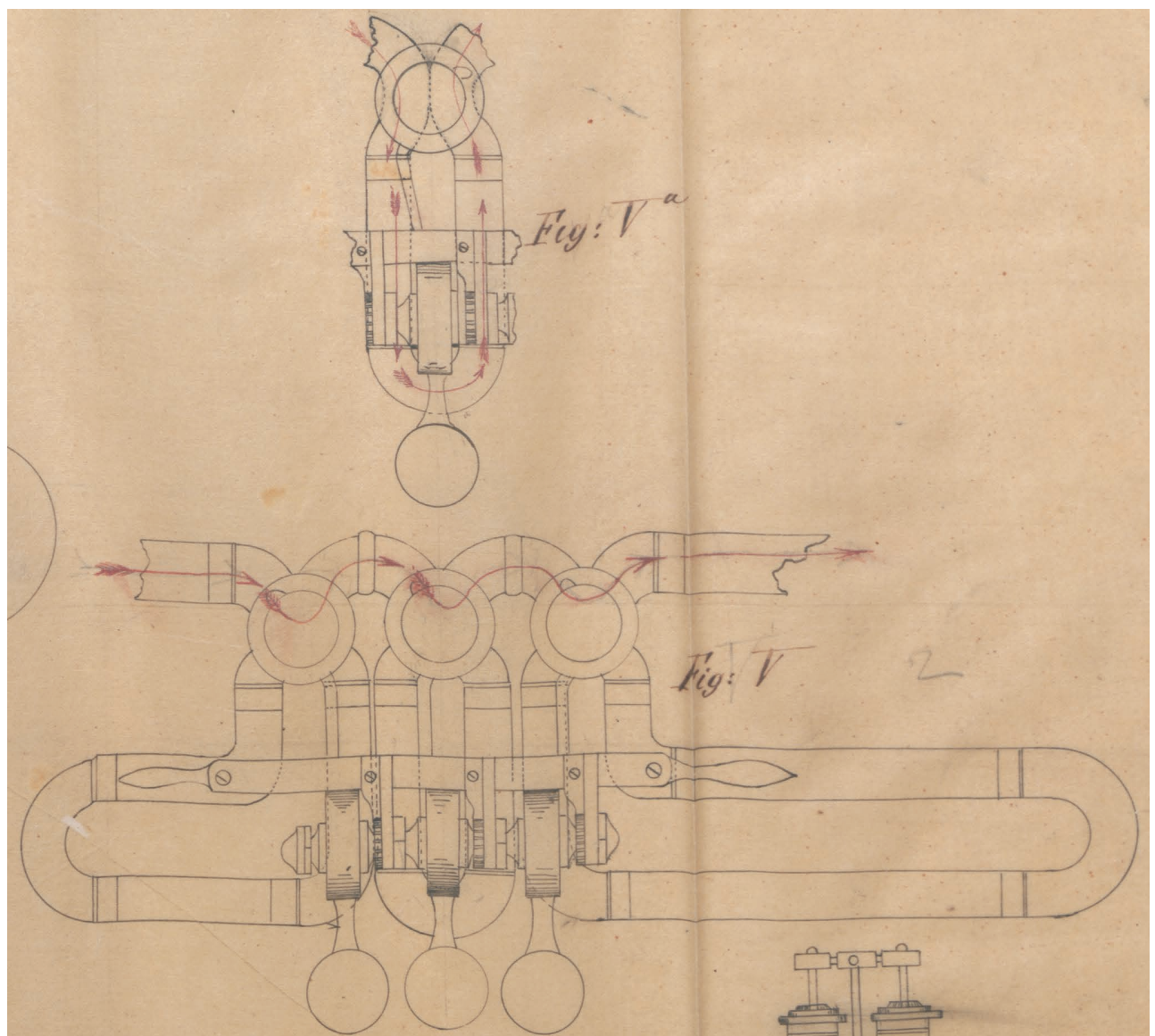

Figure 3 Rotary valves with a smoother windway in Sax's 1862 patent (@) IN PI) 


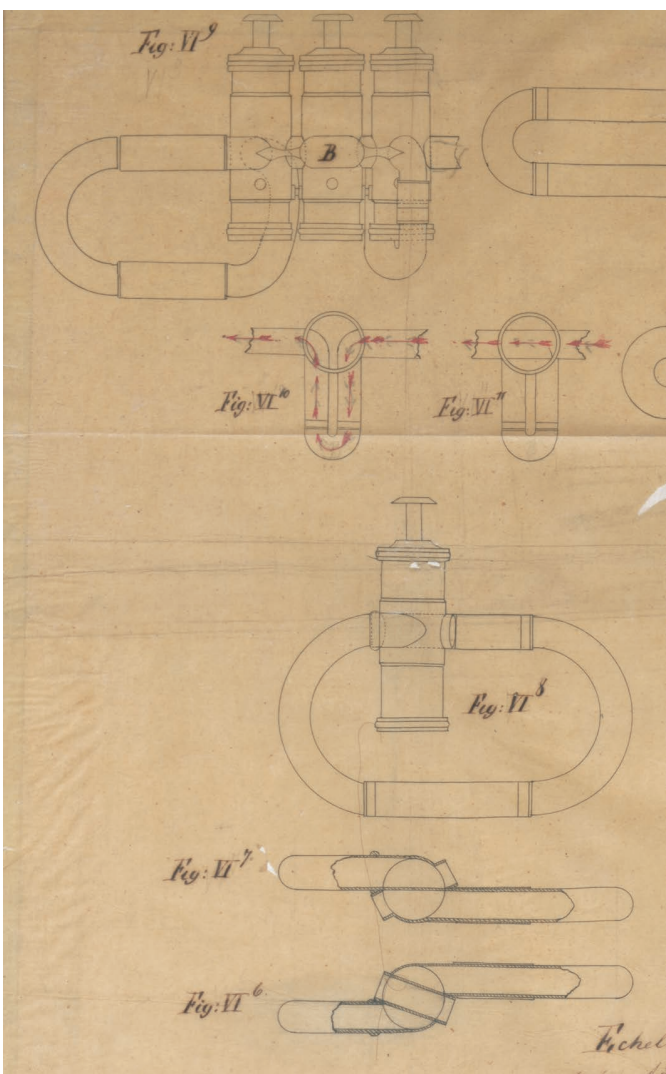

FIGURE 4 The Berlin valve in Sax's 1862 patent, combining the smooth windway of the rotary valve with the simple operating mechanism of the Stölzel valve (@) INPI)

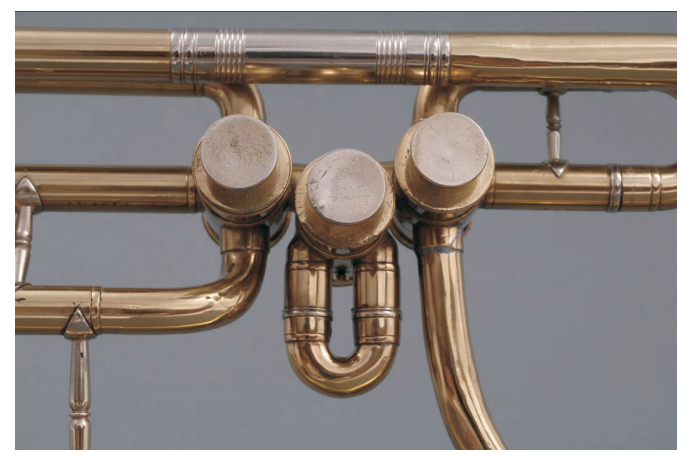

FIGURE 6 Exit and re-entry of valve loops at $90^{\circ}$ angles in an unsigned Prussian cornet. National Music Museum, University of South Dakota, Vermillion (NMM 6861)

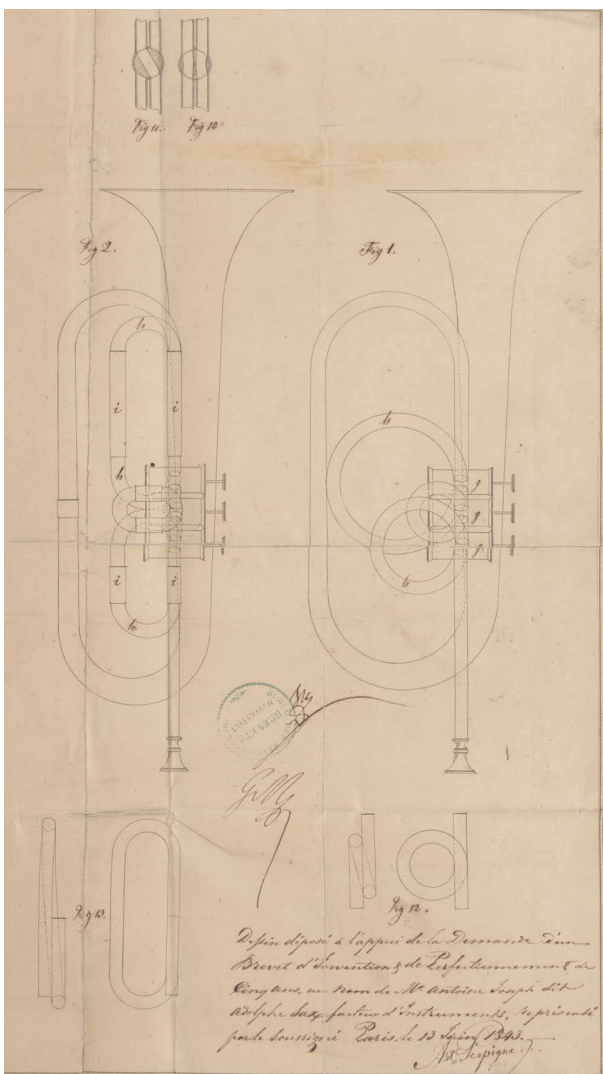

FIgURE 5 Circular valve loops inspired by crooks in Sax's French patent No. 15364 of 17 August 1843 (@) IN PI)

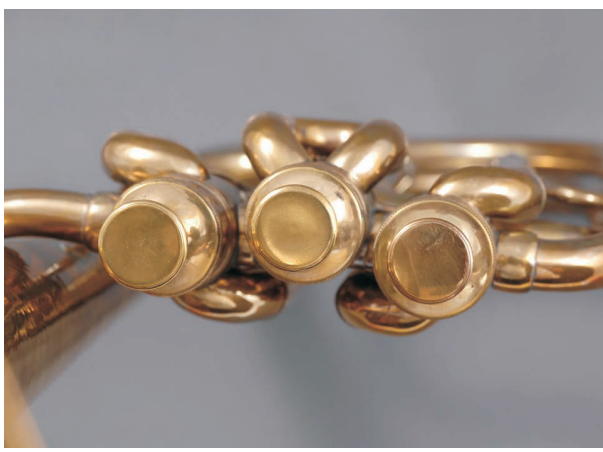

FIGURE 7 Exit and re-entry of valve loops at various inclinations in a saxhorn by Adolphe Sax (N M M 7166) 


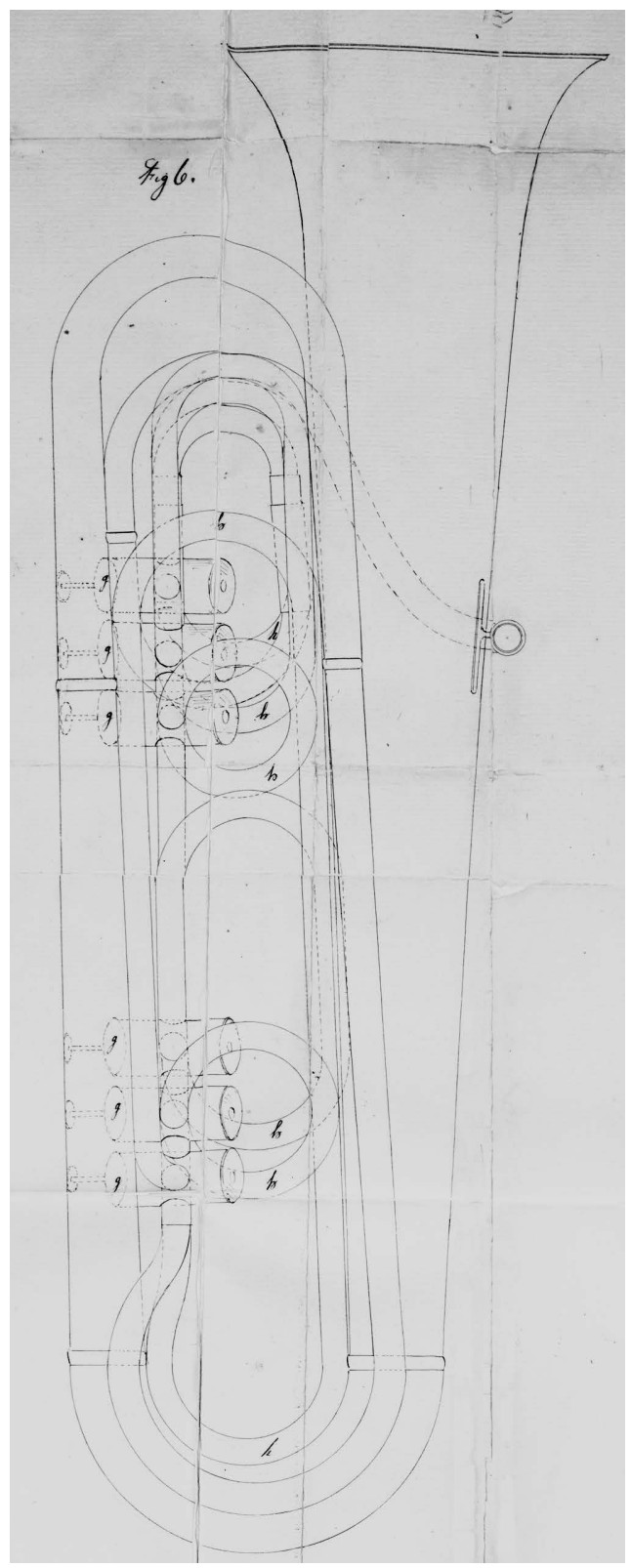

FIGURE 8 Contrebasse d'Harmonie en Fa with six valves from Sax's 1843

patent (@ INPI)

for an expanded compass - not just five - and an upright bell. According to the Prussian patent law, this modification was enough to ensure that Sax did not infringe Wieprecht's and Moritz's patent rights; in any case, their patent was only valid within the Prussian monarchy, not in France.

Sax's drawings of saxhorns and saxotrombas in his patent application of I October I845 provide the most comprehensive source for comparison with Wieprecht's instrument models (Figure 9). The Prussian models are well documented in hand drawings by Wilhelm Petzold (I8I2-I886), the first music teacher hired by the town of Markneu- 


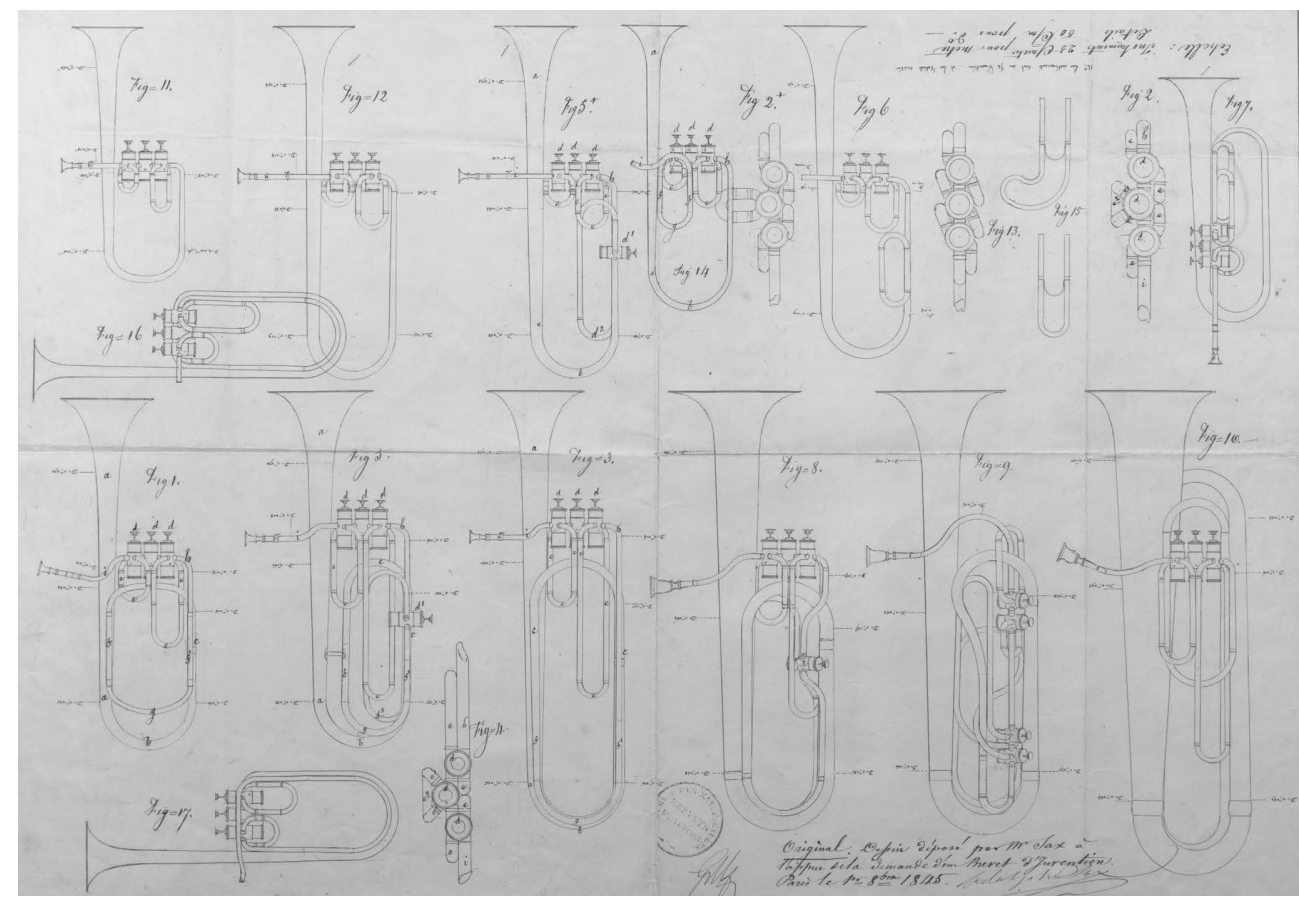

FIGURE 9 Drawing of saxhorns and saxotrombas in Adolphe Sax's 1845 patent (French patent No. 2306; () IN PI)

kirchen in $1834 .{ }^{\mathrm{I}} \mathrm{I}$ will compare these two sources and a few instruments to examine whether there is any justification to Wieprecht's claim that Sax plagiarised his instrument models.

Most of Sax's models are principally inspired by the upright bell of Wieprecht's bass tuba, and all of them have Berlin valves, but none of them are an exact copy of Wieprecht's designs. Wieprecht took his inspiration for a whole family of uniformly scaled brass instruments from the single-tone Russian horn ensemble (Figure ro). He therefore opted for a more or less conical bell for his whole instrument family in order to achieve a similarly uniform timbre. A draft of a prospectus for the trade firm Herold in Klingenthal from the mid-1850s, based on Petzold's drawings, shows a cornettino, cornetto, and a cornetto alto, all with a distinctly conical bell (Figure II).

Cornettino and petit saxhorn en mi-bémol (soprano) Comparing individual sizes of Wieprecht's Prussian cornet models with Sax's saxhorns and saxotrombas reveals clear

Enrico Weller: Die Geschichte des Markneukirchner Stadtorchesters bis I945, in: I50 Jahre Stadtorchester Markneukirchen e.V. Festschrift, Markneukirchen 2003, pp. 24-27. Petzold's drawings survive at the Musikinstrumentenmuseum in Markneukirchen, T 56: Blechblasinstrumente. My thanks to Heidrun Eichler for allowing me to view this source. 


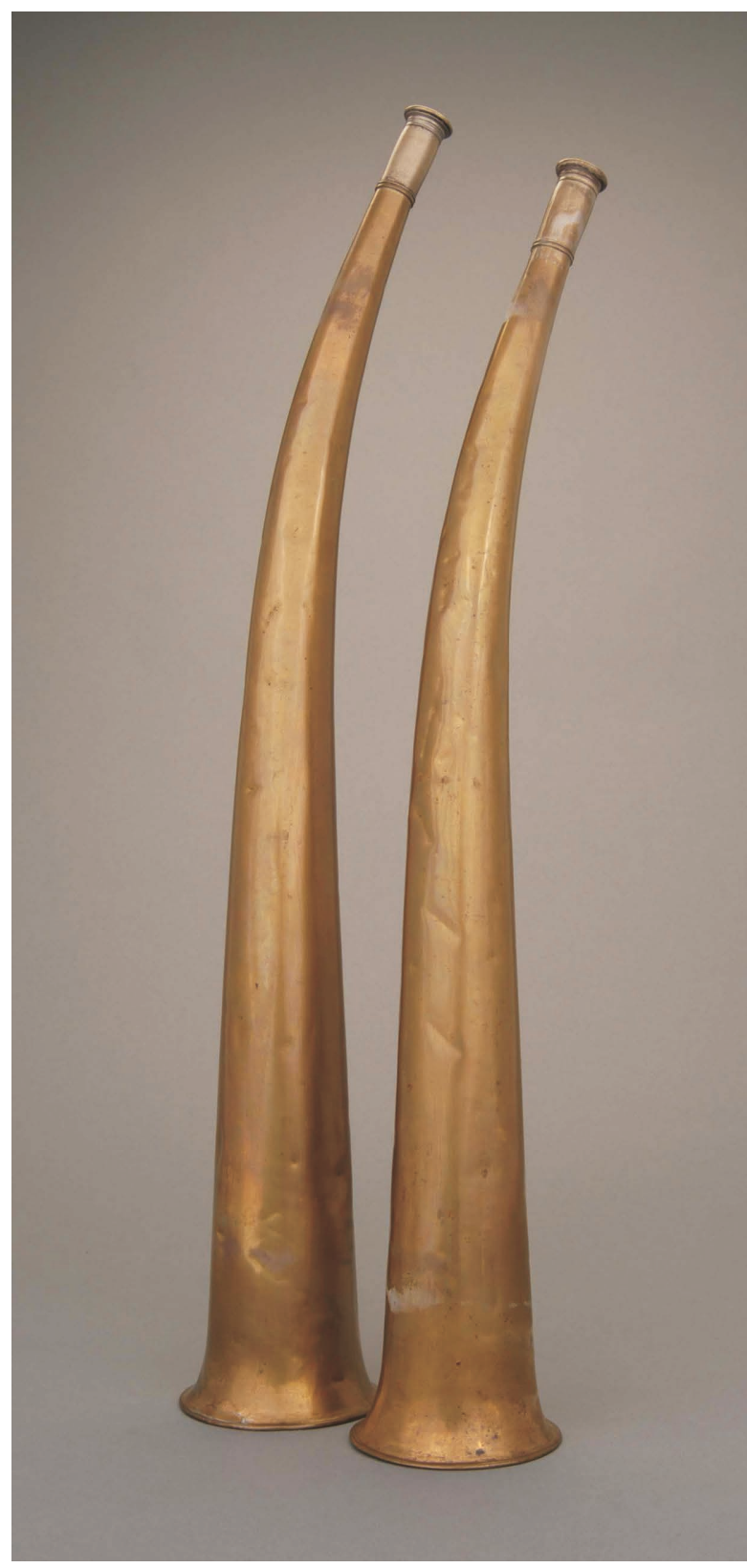

FIgURE 10 Russian horns for $f^{1}$ and $f$-sharp ${ }^{1}$, Germany, nineteenth century ( $N$ M M 7275 and 7276)
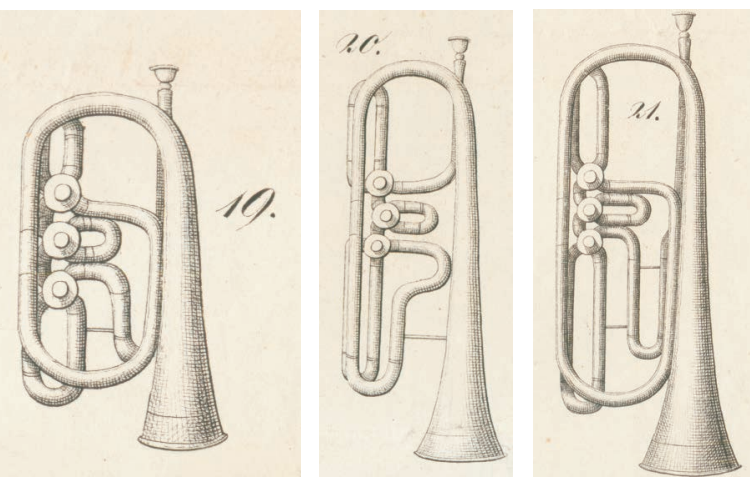

FIGURE 11 Drawings by Wilhelm Petzold in a prospectus for the trade firm Herold in Klingenthal, circa 1850. The barely flaring bell-shape is inspired by Russian horns. (c) Musikinstrumentenmuseum Markneukirchen, T 56: Blechblasinstrumente) 
differences, showing that while Sax was inspired by Wieprecht's idea of homogeneous instrument families, he by no means copied them slavishly. Eugenia Mitroulia has pointed out that the saxhorn en mi-bémol (soprano) is No. II in the I845 patent (in Figure 9 here). ${ }^{\text {I7 }}$ This size was available in two forms: bell front and bell upright, as can be seen, for example, in Sax's prospectus for the I85I Great Exhibition in London. ${ }^{\mathrm{I}}{ }^{8}$ Sax called the instrument with upright bell petit saxhorn en mi bémol (Cavalerie), while he specified the bell-front version for the infanterie. Wieprecht did not offer an upright bell version of the cornettino. If we compare the bell profile of a typical Prussian soprano cornet in 4 -foot $\mathrm{C}$ by Carl Wilhelm Moritz of Berlin in circa I842/43 ${ }^{\mathrm{I} 9}$ with a high $\mathrm{E} b$ petit saxhorn from I859 by Sax (NMM 7307), we see that there was a very different concept behind them. The strictly conical bell of the Prussian cornet bears no resemblance whatsoever to the petit saxhorn's flaring bell. In addition, the bell throat of the Prussian cornet is much wider than that of the saxhorn, which in turn has a much wider bell flare (Figure I2).

Cornetto and contralto saxhorn en si-bémol Several surviving drawings by Petzold show the Prussian cornetto in B b, in all cases with Berlin valves and a barely flaring bell. In Sax's I845 patent the Saxhorn en si-bémol is illustrated with an upright bell (No. I2 in Figure 9 here). In the I85I prospectus it is found in upright bell formation for the cavalry (to direct the bell away from the horse's head) and a bell-front version for the infantry. ${ }^{20}$

A comparison of a typical Prussian cornet NMM 686I (Figure I4) with Sax's contralto saxhorn NMM 7I22 (Figure I5), both in $4^{1 / 2}$-foot B b, reveals the differences between them. The bell is almost conical in the Prussian cornet, while it is widely flaring in the saxhorn. In the Prussian cornet the valve loops are arranged at $90^{\circ}$ angles to the main windway, while they are inclined in the saxhorn (the second valve is actually a Périnet valve). The Prussian cornet is held with the loop to the side, like a modern German rotary valve trumpet, while the saxhorn is played with the loop below the bell, like a modern pistonvalve trumpet.

Although the difference in the bell flare is less pronounced here than in the soprano instruments discussed previously, it is still very noticeable; the Prussian cornet (Figure I7, blue) is not only narrower than the saxhorn (Figure I7, red) at the bell flare, but also at the bell throat. Other crucial measurements also differ considerably. While the

17 Eugenia Mitroulia: Adolphe Sax's Brasswind Production with a Focus on Saxhorns and Related Instruments, Edinburgh 20II, p. I37, www.era.lib.ed.ac.uk/handle/I842/5490 (22. June 20I8).

18 Reproduced in Malou Haine/Ignace De Keyser: Catalogue des Instruments Sax au Musée instrumental de Bruxelles, Brussels I980, p. I87.

19 Berlin Musical Instrument Museum, No.3096. My thanks to Conny Restle and Tom Lerch for allowing me to examine this instrument. Ibid. 


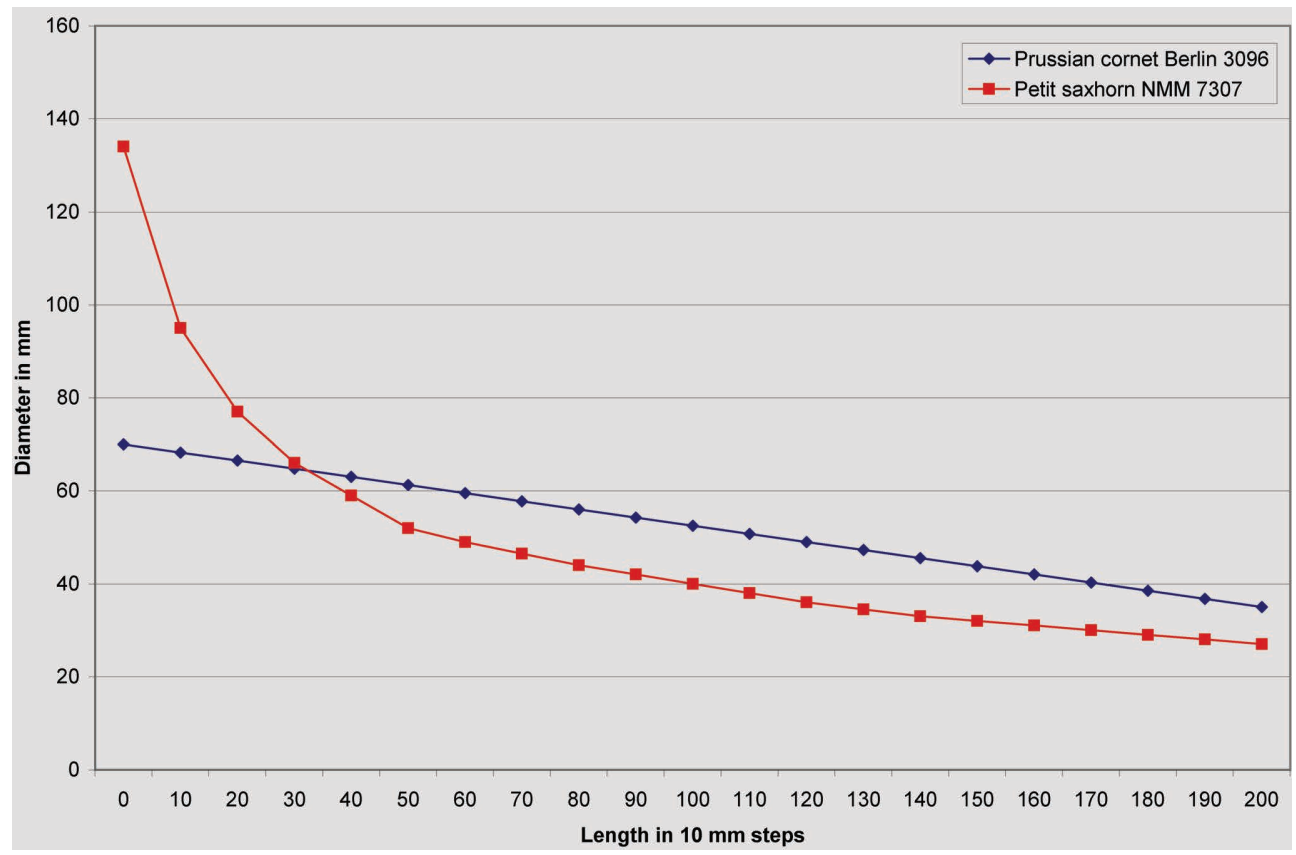

FIGURE 12 Comparison of bell profiles between a Prussian soprano cornet by Carl Wilhelm Moritz (Berlin Musical Instrument Museum, No. 3096, blue) and a petit saxhorn in 31/4-foot Eb by Adolphe Sax (N M M 7307, red)

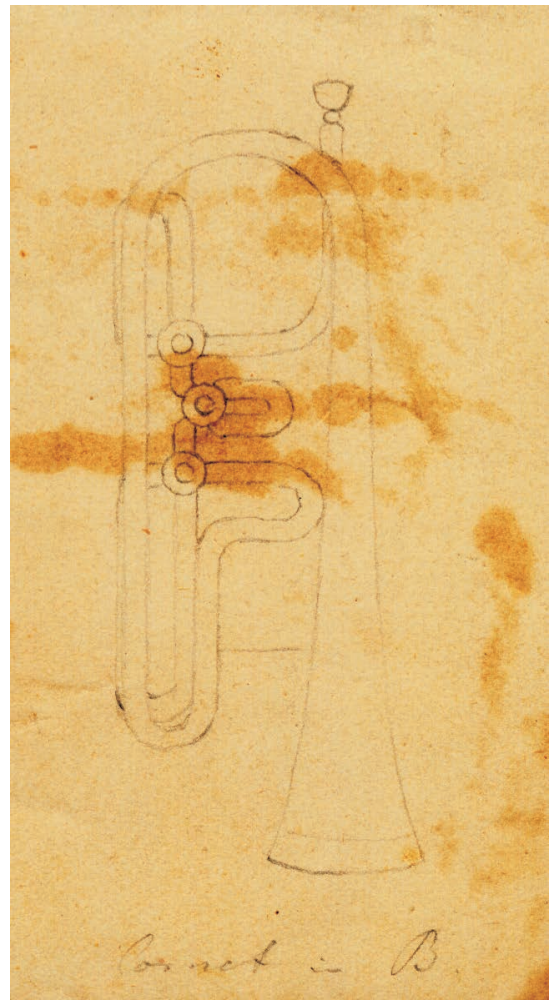

FIgure 13 Drawing of a Prussian cornet in B b with barely flaring bell by Wilhelm Petzold

(C) Musikinstrumentenmuseum

Markneukirchen, T 56) 


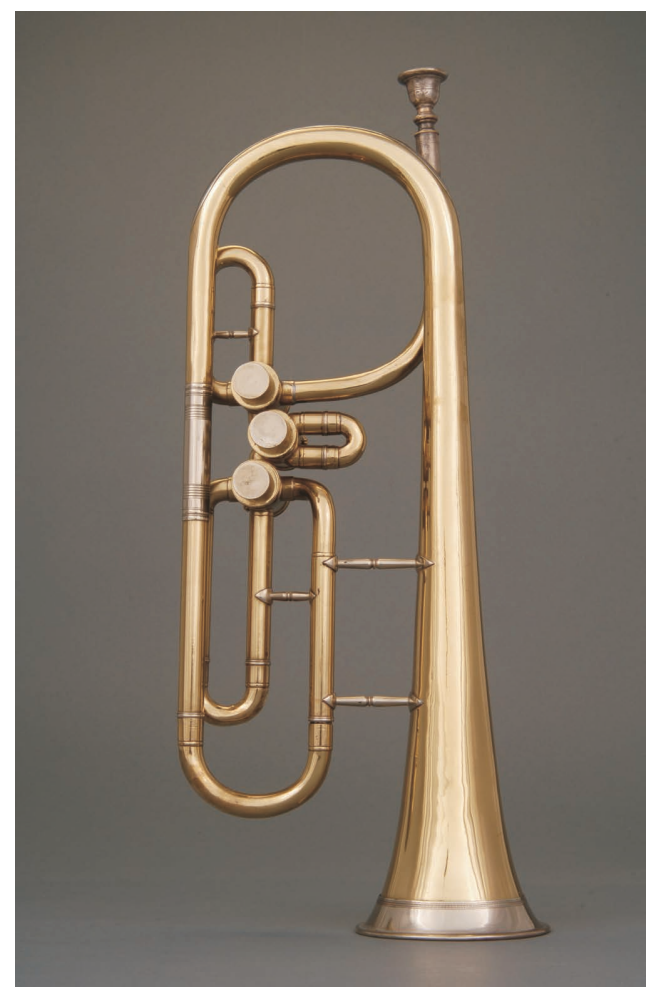

FIGURE 14 Unsigned Prussian cornet in

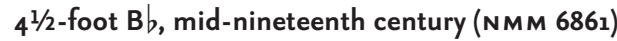

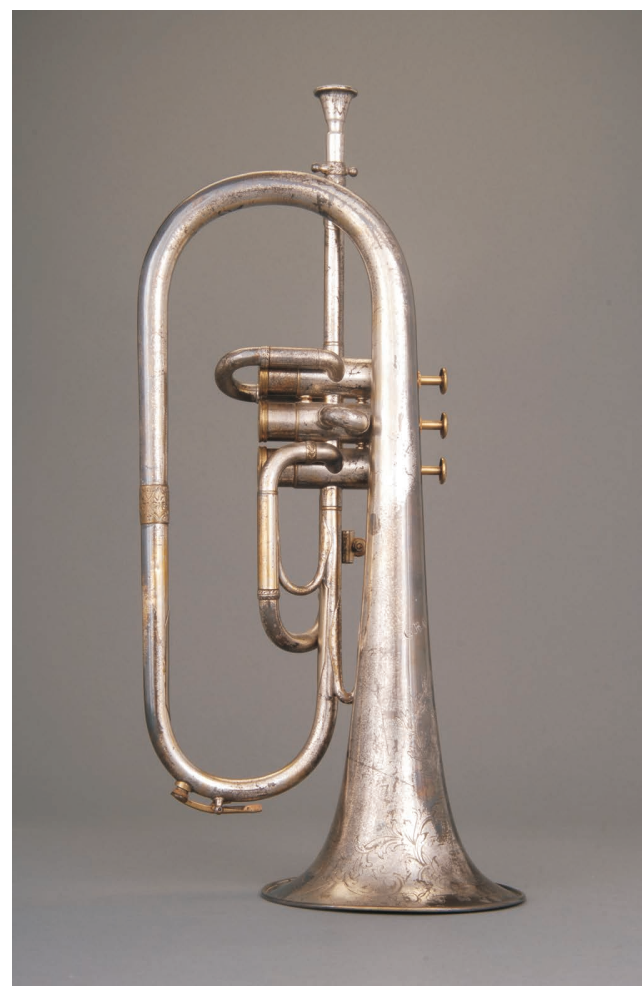

FIGURE 15 Contralto saxhorn in $4^{1 / 2}$-foot $B$ by Adolphe Sax, Paris, 1870 (N M M 7122)

saxhorn has a telescopic tuning slide at the beginning of the leadpipe, the main tuning slide of the Prussian cornet is located after the valve section. This leads to a more cylindrical bore profile in the Prussian cornet with a smaller mid-point diameter of $10.7 \mathrm{~mm}$, while the saxhorn is more conical with a much larger mid-bore diameter of I5.I mm (internal measurements, see Figure I6). These differences in bore profiles and bell shapes lead to noticeably different acoustical properties: the wider bore profile of the saxhorn results in much stronger resonance peaks in the lower modes (Figure I8, red), while the Prussian cornet has stronger higher resonance peaks (Figure I8, blue).

internal diameter leadpipe internal diameter leadpipe minimum internal diameter valve slides internal mid-bore diameter

$\begin{array}{ll}\text { Prussian Cornet } & \text { Saxhorn } \\ \text { NMM 686I } & \text { NMM 7I22 } \\ \text { II.I } & \text { I0.2 } \\ \text { IO.6 } & \text { IO.I } \\ \text { IO.7 } & \text { IO.4 (9.9) } \\ \text { II.5 } & \text { I5.I }\end{array}$

FIGURE 16 Comparison of important bore measurements between the Prussian cornet NMM 6861 and the saxhorn NMM 7122 (all measurements in millimetres). In NMM 7122 the internal diameter of the first valve slides is smaller than that of the other two. 


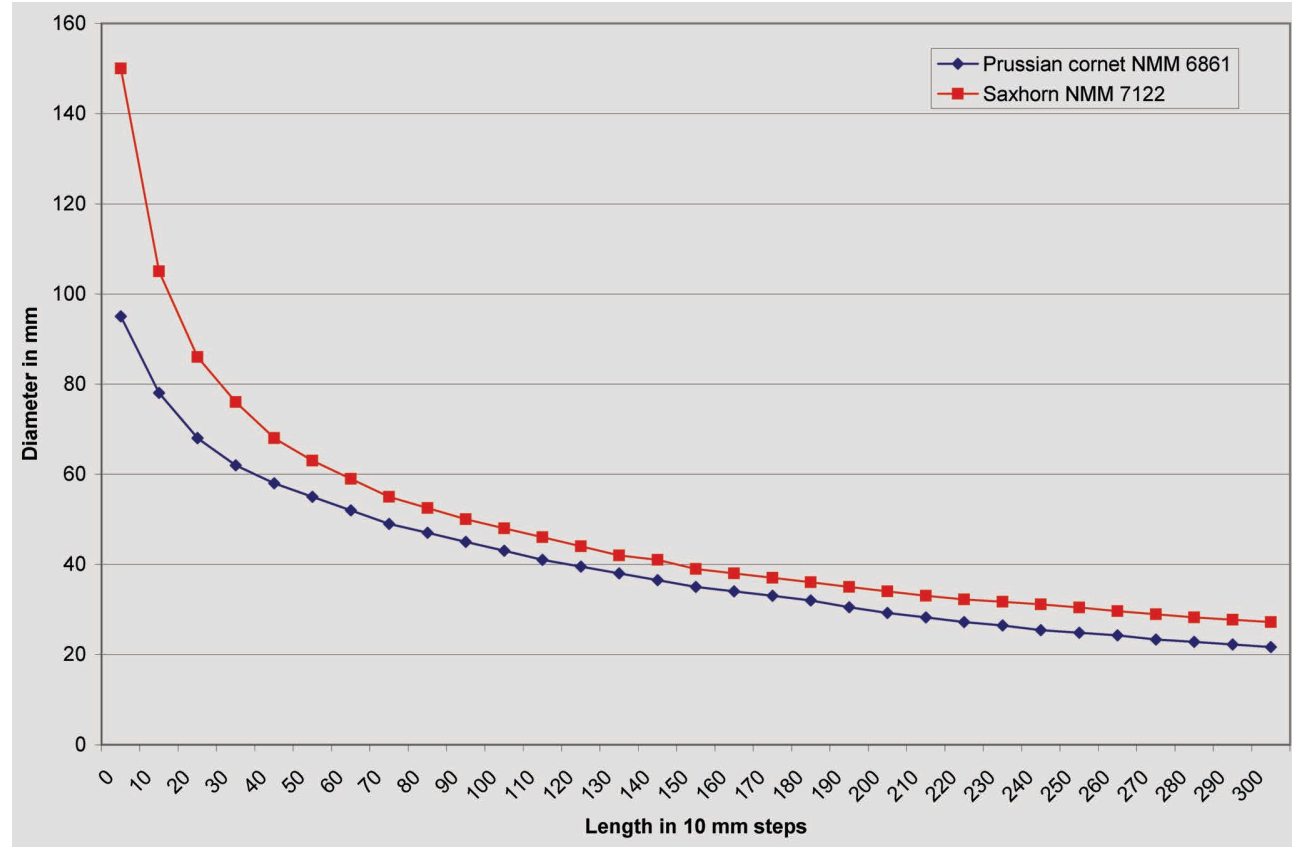

FIGURE 17 Bell profile comparison between the Prussian cornet NMM 6861 (blue) and the contralto saxhorn NMM 7122 (red)

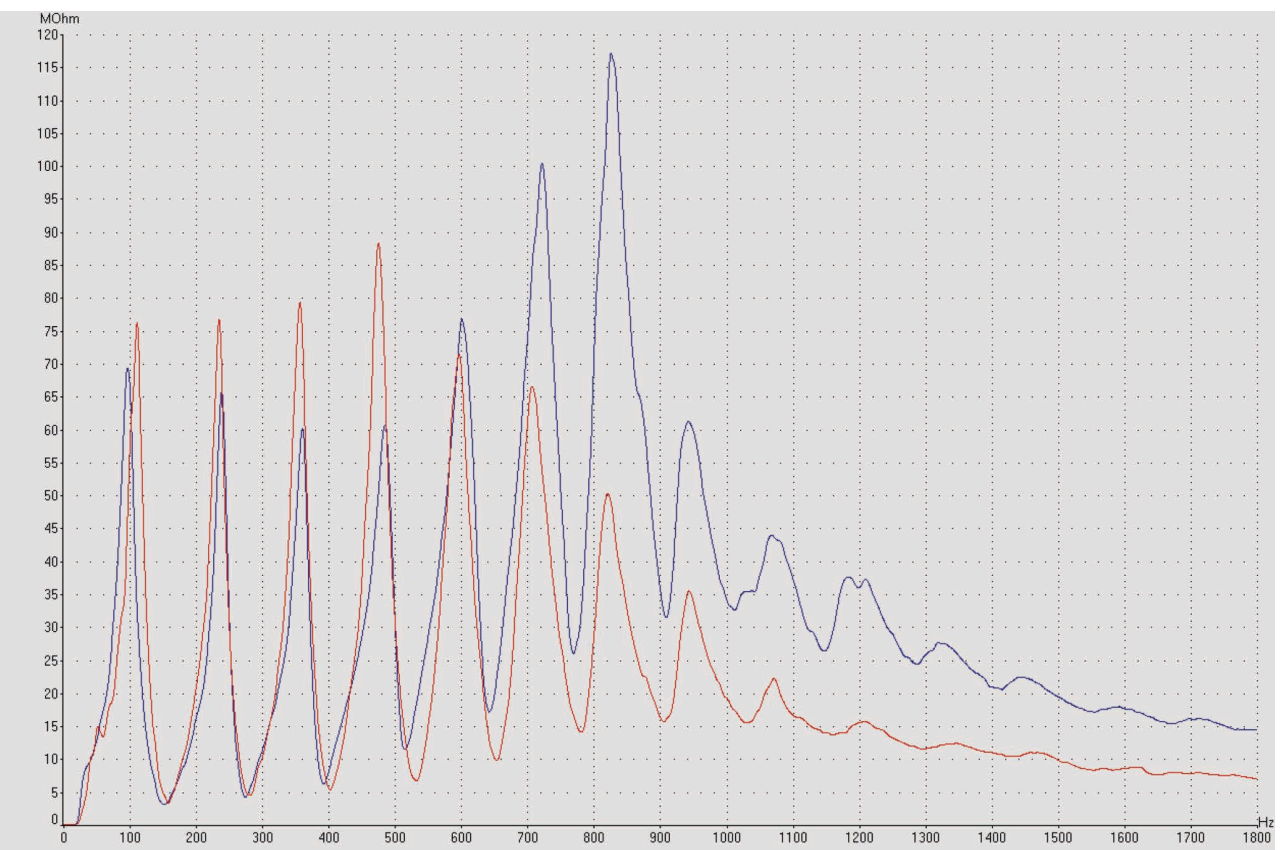

Color Weight Measurement

- Unweighted 6861_12 Vo 2010.06.02

FIgURE 18 Comparison of acoustic impedance of the Prussian cornet NMM 6861 (blue) and the contralto saxhorn NMM 7122 (red) 
Cornetto alto and saxhorn en mi-bémol Several drawings of an alto cornet in 6-foot $\mathrm{F}$ are found among Petzold's papers (Figure I9); it was also made in $61 / 2$-foot $\mathrm{E} b$, the size that Wieprecht compares to the saxhorn en mi-bémol. In Sax's I845 patent, the Eb alto size is represented by No. I (in Figure 9 here). This is one of two instruments that Eugenia Mitroulia has identified as the narrower-bore saxotromba en mi-bémol, not as a saxhorn, the other one being the baritone in 9-foot $\mathrm{B} b .{ }^{2 \mathrm{I}} \mathrm{The} \mathrm{E}$ b saxotromba only existed in upright bell formation; this bell orientation was in fact the distinguishing feature of the saxotromba family according to the I 845 patent. Alto cornets of the Prussian tradition, on the other hand, were made in bell-front configuration. Two instruments in the Utley Collection at the National Music Museum in Vermillion resemble the drawings by Petzold and Sax closely: the unsigned Prussian alto cornet in 61/2-foot $\mathrm{E} b$ NMM 7015 (Figure 20) and the saxotromba NMM 7I66 of the same size (Figure 2I). The alto cornet NMM 70I5 has a much wider final bell flare than all other Prussian instruments discussed thus far, possibly

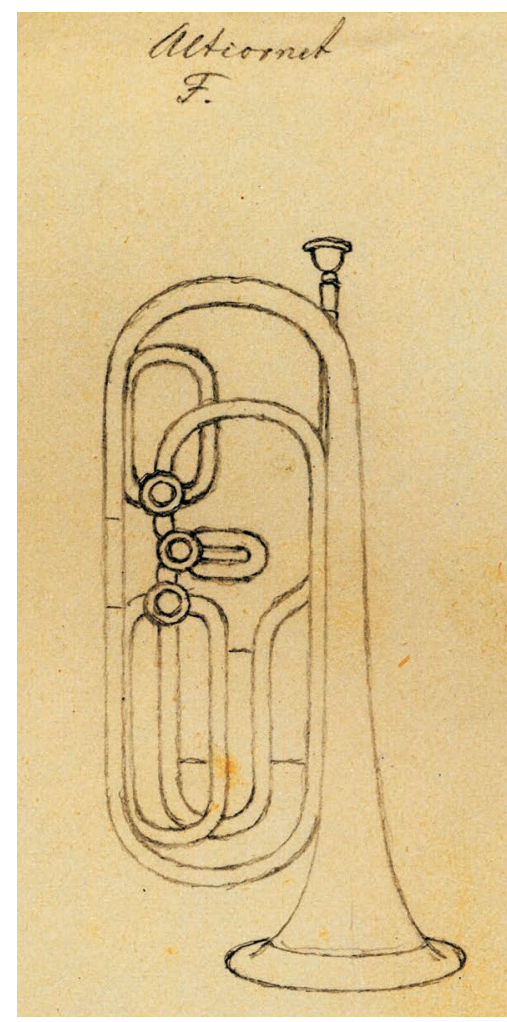

FIgure 19 Drawing of a Prussian alto cornet in 6-foot $\mathrm{F}$ by Wilhelm Petzold (@) Musikinstrumentenmuseum Markneukirchen, T 56)

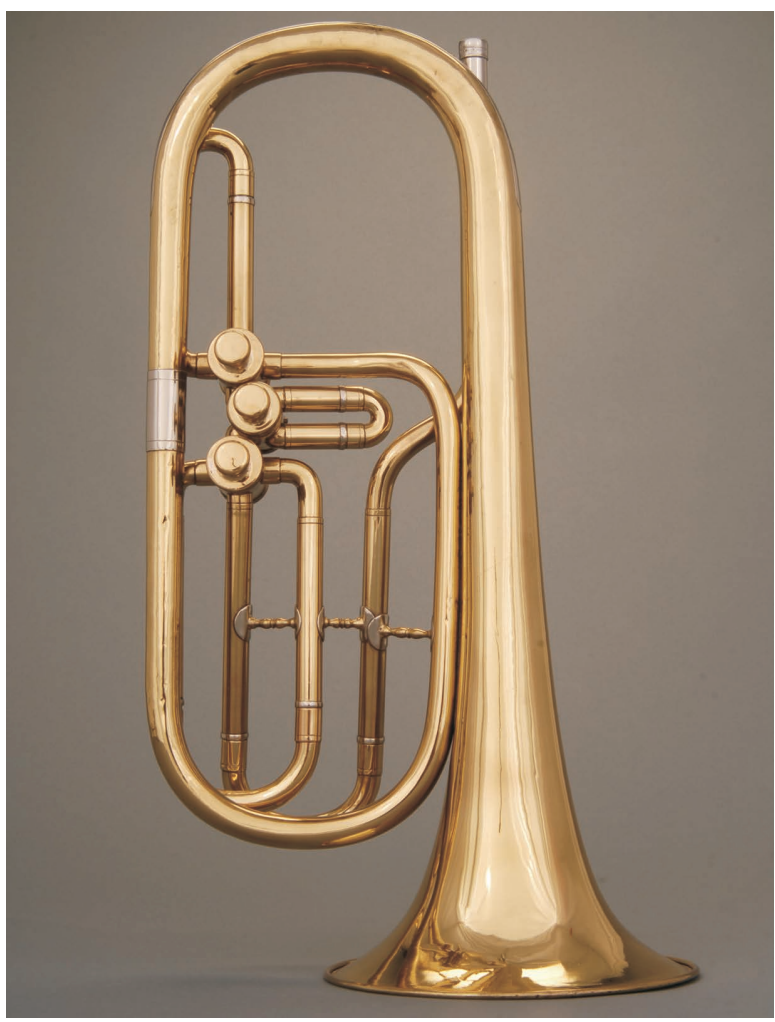

FIgURE 20 Unsigned Prussian alto cornet in 61/2-foot Eb, circa $1865-1885$ (NMM 7015) 

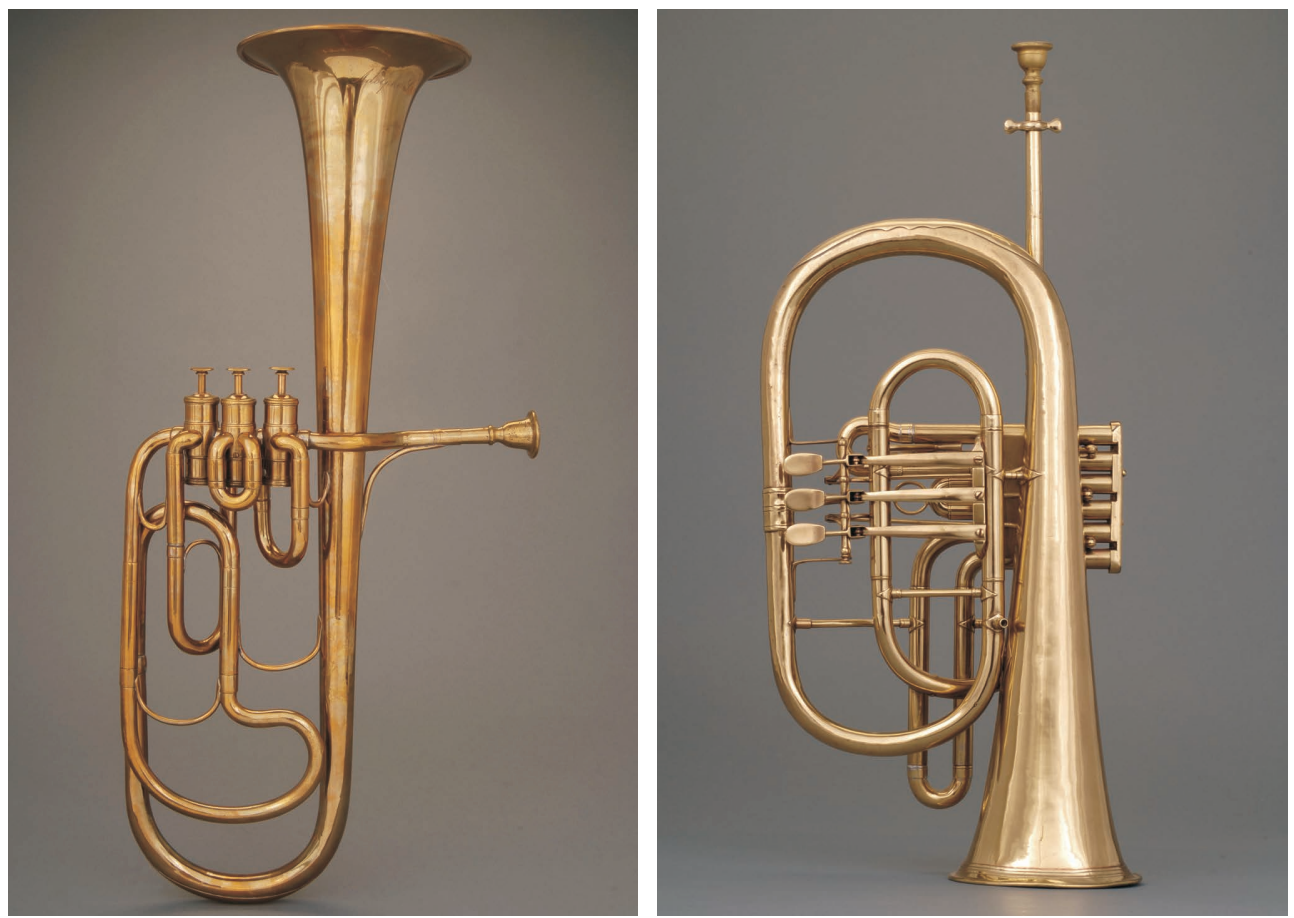

FIGURE 21 Saxotromba in 61/2-foot $E$ b by Adolphe Sax, Paris, 1848 (N M M 7166)
FIGURE 22 Alto cornet in 6-foot F by Franz Kaiser, Cincinnati, Ohio, between 1855 and 1857 (NMM 7072)

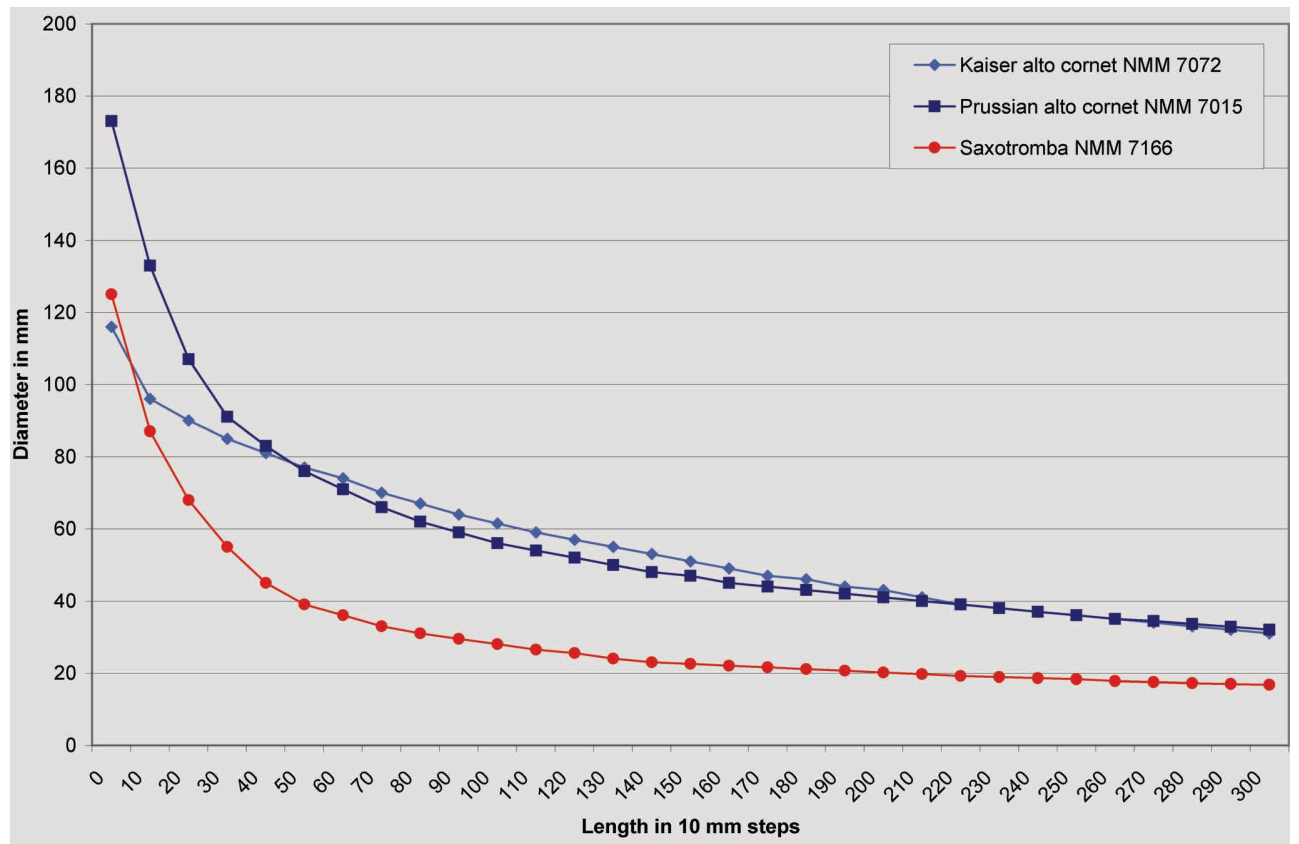

FIGURE 23 Comparison of bell profiles of the alto cornets NMM 7015 (dark blue) and NMM 7072 (light blue) with the saxotromba NM M 7166 (red) 
influenced by Austrian flugelhorn and alto horn designs. Petzold shows several alto cornets with flaring bell among his drawings, while the conical-bell model is found in the Herold prospectus (No. 2I in Figure II here). An alto cornet in 6-foot F by the Markneukirchen emigrant Franz Kaiser, made in Cincinnati between I855 and I857 (NMM 7072, Figure 22), features the conical bell version (though with double-piston valves).

A comparison of the bell profiles of the two alto cornets of the Prussian tradition (Figure 23, light and dark blue) with the saxotromba (Figure 23, red) shows that the cornets have a much wider throat than the saxotromba. However, because the bell flare is much less pronounced in the alto cornet by Kaiser, its final bell diameter is smaller than that of the saxotromba. A bore profile comparison shows that the saxotromba has a wider bore than the Prussian alto cornets at the mid-point of the tube length (Figure 24).

$\begin{array}{llll} & \text { Alto cornet } & \text { Alto cornet } & \text { Saxotromba } \\ & \text { NMM 7072 } & \text { NMM 70I5 } & \text { NMM 7I66 } \\ \text { internal diameter receiver/minimum } & \text { II.8/II.2 } & \text { II.8/II.4 } & \text { II.3 } \\ \text { internal diameter at valve slides } & \text { IO.9 } & \text { II.4 } & \text { II.2 } \\ \text { internal diameter at tuning slide } & \text { II.3-I2.2 } & \text { II.4 } & \text { II.2-I2.2 } \\ \text { internal mid-bore diameter } & \text { I3.7 } & \text { I4.2 } & \text { I5.2 }\end{array}$

FIGURE 24 Comparison of important bore measurements between the alto cornets NMM 7015 and 7072 and the saxotromba NMM 7166 (all measurements in millimetres)

Conclusion Even without pursuing further my comparison between Sax's designs and the lower sizes of the Prussian instrument models such as the tuba, I hope to have made my point sufficiently clear: Sax did not merely copy Wieprecht's designs, but changed and improved them considerably. We can therefore agree with Wieprecht's assessment of Sax that "a useful improvement can be as laudable as an invention." ${ }^{22}$ Wieprecht's viewpoint and his criticism become understandable when seen in the context of the Prussian patent law of the time, in which only entirely new inventions merited patent protection, while improvements did not. In France, patent law also protected useful changes and improvements to existing designs, which were primarily the subject of Sax's patents. Sax was indeed inspired by Wieprecht's idea of a uniform instrument family, the upright bell of the bass tuba, and the Berlin valve. However, he changed the bore and bell profiles considerably, applied the upright bell to a whole brasswind family, and improved the valve system. In the end, Sax's improvements were far more successful than the German inventions on which they had been based. Without Sax's input, the international success of valve-brass instruments and uniform brasswind families would never have been so extensive and so swift, nor would it have been so far-reaching. 


\section{Inhalt}

Vorwort 7

Adrian von Steiger "Agilité, homogénéité et beauté". The Saxhorn in the Context of the Opéra and Military Music 9

Eugenia Mitroulia/Arnold Myers The Saxhorn Families I8

Malou Haine Une nouvelle source d'archives pour identifier les marques de fabrique de facteurs d'instruments de musique (I860 à I9I9)

Stewart Carter Kastner, the Distin Family, and the Emergence of the "New" Brasswind Instruments by Adolphe Sax 68

Sabine K. Klaus Wieprecht versus Sax. German Roots of Adolphe Sax's Brasswind Designs 97

Ignace De Keyser The Construction of the Genius in

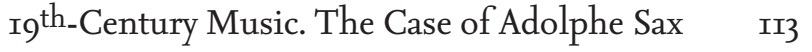

Cyrille Grenot Deux faillites d'Adolphe Sax, I873 et I877. Présentation et documents $\quad$ I46

Reimar Walthert The First Twenty Years of Saxhorn Tutors $\quad 155$

Bruno Kampmann French Makers' Improvements on Brass Instruments in the mid-I th $^{\text {th }}$ Century, Compared with Those by Adolphe Sax $\quad$ I68

Jeroen Billiet Adolphe Sax's Ultimate Masterpiece. The History, Design and Use of the Cor Sax à six pistons indépendants $\quad$ I76

Daniel Allenbach „Une réforme tellement logique« oder »à classer au rang des utopies«? Henri Chaussiers »instruments en Ut« $\quad$ I88

Gregor Widholm Das Wiener Horn - ein Instrument des I9. Jahrhunderts als erste Wahl in Orchestern des 2I. Jahrhunderts 223

Martin Skamletz »... und gar nichts, wodurch sich der eigene schöpferische Geist des Komponisten beurkundete«. Cherubini, Hummel, Konzerte, Opern, Quodlibetes und Trompeten in Wien zu Beginn des I9. Jahrhunderts.

Teil 3 und Schluss: Anton Weidinger und sein Instrument 245

Rainer Egger/Martin Mürner $\quad$ Restaurierungsergebnisse messbar machen $\quad 262$ Namen-, Werk- und Ortsregister 272

Die Autorinnen und Autoren der Beiträge $\quad 283$ 


\section{DAS SAXHORN}

Adolphe Sax' Blechblasinstrumente im Kontext ihrer

Zeit. Romantic Brass Symposium 3 - Herausgegeben von Adrian von Steiger, Daniel Allenbach und Martin Skamletz 


\section{MUSIKFORSCHUNG DER Hochschule der KÜnste Bern Herausgegeben von Martin Skamletz und Thomas Gartmann}

Band 13 
2 Dieses Buch ist in gedruckter Form im April 2020 in erster Auflage in der Edition Argus in Schliengen/Markgräflerland erschienen. Gestaltet und gesetzt wurde es im Verlag aus der Seria und der SeriaSans, die von Martin Majoor im Jahre 2000 gezeichnet wurden. Gedruckt wurde es auf Eos, einem holzfreien, säurefreien, chlorfreien und alterungsbeständigen Werkdruckpapier der Papierfabrik Salzer im niederösterreichischen Sankt Pölten. Das Vorsatzpapier Caribic cherry wurde von Igepa in Hambug geliefert. Rives Tradition, ein Recyclingpapier mit leichter Filznarbung, das für den Bezug des Umschlags verwendet wurde, stellt die Papierfabrik Arjo Wiggins in Issy-les-Moulineaux bei Paris her. Das Kapitalband mit rot-schwarzer Raupe lieferte die Firma Dr. Günther Kast aus Sonthofen im Oberallgäu, die auf technische Gewebe und Spezialfasererzeugnisse spezialisiert ist. Gedruckt und gebunden wurde das Buch von der Firma Bookstation im bayerischen Anzing. Im Internet finden Sie Informationen über das gesamte Verlagsprogramm unter www.editionargus.de, zum Institut Interpretation der Hochschule der Künste Bern unter www.hkb.bfh.ch/interpretation und www.hkb-interpretation.ch. Die Deutsche Nationalbibliothek verzeichnet diese Publikation in der Deutschen Nationalbibliografie; detaillierte bibliografische Daten sind im Internet über www.dnb.de abrufbar. (C) der zeitgleich erschienenen digitalen Version: die Autorinnen und Autoren, 2020. Dieses Werk ist lizenziert unter einer Creative Commons Namensnennung-Nicht kommerziell 4.0 International Lizenz (CC BY-NC 4.o). DOI: https://doi.org/I0.26045/kp64-6I77 ISBN 978-3-93I264-93-2 